AGRICULTURE AND BIOLOGY JOURNAL OF NORTH AMERICA

ISSN Print: 2151-7517, ISSN Online: 2151-7525, doi:10.5251/abjna.2013.4.4.406.412

(C) 2013, ScienceHuß, http://www.scihub.org/ABJNA

\title{
Improving potato tuber yields using genotypes with multiple virus resistance in Kenya
}

\author{
Onditi John $^{1 *}$, Njoroge Kiarie ${ }^{2}$ and Shibairo Solomon ${ }^{2}$ \\ ${ }^{1}$ Kenya Agricultural Research Institute (KARI), National Potato Research Centre (NPRC), \\ Tigoni, P.O. Box 338 - 00217 Limuru, Kenya \\ ${ }^{2}$ University of Nairobi, Department of Plant Science and Crop Protection \\ P.O. Box 29053-00100, Nairobi, Kenya \\ *Corresponding author: J. O. Onditi, Email: john3oju@yahoo.com
}

\begin{abstract}
Potato (Solanumtuberosum L.) viruses play a major role in lowering yields and quality of ware and seed tubers in Kenya. This experiment was conducted to determine potential of potato clones with multiple virus resistance in minimizing virus related crop losses. The trials were conducted in two sites for four successive seasons of re-using seed tubers. The genotypes were exposed to natural sources of virus infection without spraying insecticides to control (aphids) virus vectors. Genotypes with multiple virus resistance experienced significant $(P \leq 0.05)$ lower rate of yield loss $(21.2 \%)$ compared to the major local varieties (68.4\%). There was successful identification of a higher yielding virus resistant clone (CIP396286.7) with significant $(P \leq 0.05)$ higher mean yield (30.3 T/ha) compared to the highest yielding local variety $(24.3 \mathrm{~T} / \mathrm{ha})$, Tigoni. The number of tubers per plant was significantly $(P \leq 0.05)$ higher $(12.1)$ in the virus resistant clones than in the local varieties (7.3). Reduced rate of yield loss, higher yield performance and higher number of tubers per plant in the tested clones was attributed to genetic contribution of multiple virus resistance. Virus related crop losses currently experienced by local farmers can be minimized with use of such virus resistant genotypes.
\end{abstract}

KEY WORDS: Potato, yield, virus resistance, Kenya

\section{INTRODUCTION}

The potato (Solanum tuberosum L.) crop makes a significant contribution to food security in Kenya as the second most widely grown food crop after maize. Major constraints of potato production include high incidence of pests and diseases and lack of sufficient quantity of certified seed tubers (Schulte-Geldermann et al., 2012). Among the important diseases of potato in the country, viruses have been a major concern because of the role they play reducing seed tuber quality and the associated crop losses (Muthomi et al., 2009). In many cases, viral infection in potato crop results in poor yields and vegetative growth accompanied by symptoms such as leaf rolling, leaf curling, leaf mosaic, inter-veinal banding, leaf drop, plant stunting and production of small or undersized tubers (Jayashigeet al., 1989; Beukema and van der Zaag 1990). Diseases severity increases over the seasons once the crop is infected leading to successive yield and crop quality losses (Hide and
Lapwood, 1992; Omer and El-Hassan, 1992; Rahman et al., 2010).

High rate of transmission of these viruses have been attributed to abundance and high rate reproduction of aphid vectors in the potato growing areas (Nderitu and Mueke, 1986; Muthomi et al., 2009; Olubayo et al., 2010). Virus indexing experiments have reported high prevalence of potato viruses in the major potato growing areas (Machangi et al., 2004; Olubayo et al., 2010; Gildemacher, 2012). The potato viruses responsible for major yield reductions are the potato virus $Y$ (PVY), potato leaf roll virus (PLRV) and potato virus $X(P V X)$, which occurs in combination with mild viruses such as potato virus $A$ (PVA), potato virus $M(P V M)$ and potato virus $S$ (PVS) to cause more severe yield losses (Kabira et al., 2006; Schulte-Geldermann et al., 2012). The highest yielding major varieties have been reported to experience yield losses due to these viruses (Lung'aho et al., 2007). Development and utilization of higher yielding and disease tolerant varieties have 
been viewed as a sustainable way of managing crop losses associated with such virus infections (MoA, 2005; MoA/GTZ-PSDA, 2009). Potato genotypes with multiple virus resistance are available at the International Potato Centre (CIP) germplasm collection (CIP, 2006) but little is known regarding resistance of these clones under the Kenyan potato growing conditions. This study was therefore conducted to determine the role of such virus resistant clones in reducing virus related crop losses.

\section{MATERIALS AND METHODS}

Genotypes, seasons and sites: Disease free in vitro plantlets obtained from CIP Lima, Peru were multiplied in tissue culture and planted in the greenhouses to produce disease free minitubers which were planted for one season in the field to produce seed for the first season trial. Prior to the first season trial, enzyme linked immune-sorbent assay (ELISA) test was conducted on tuber samples to ascertain that the tubers planted in the first season were free of six of the most important potato viruses namely: PVY, PVX, PLRV, PVS,PVM and PVA. The genotypes and their parentage were as follows:
$394903.3=(720118.1 \times$ BWH87.183 $), 395196.4=$ ([C83.621 x KATAHDIN] x BULK 1-RKN), 395438.1= $($ BWH87.344R x TXY.11), 396286.6 = $($ TXY.3 $\times 1-$ 1039), $396286.7=($ TXY.3 $\times 1-1039), 394905.8=$ (CRUZA $-148 \times$ C90.205) and $394904.17=$ (720118.1 x (C90.205)17). These genotypes were selected based on their levels of resistance to different viruses (Table 1) in addition to other locally important diseases like late blight (Phytopthora infestans Mont. de Barry) and bacterial wilt (Ralstonia solanacearum) (CIP, 2006). Three popular Kenyan varieties Asante, Tigoni and Kenya Sifa and two Ugandan varieties Nakpot 1 and Nakpot 4 were used as virus susceptible checks. Virus infected variety Tigoni (denoted Tigoni*) which had been subjected to natural virus pressure for 3 seasons in the seed field at KARI Tigoni was included as a virus infected control. The experiments were conducted at the Kenya Agricultural Research Institute (KARI)-Tigoni and at KARI-Molo (Marindas) for four seasons long rains (LR) season of 2007, short rains (SR) of 2007, LR of 2008 and during SR 2008. The seed tubers for planting each second were sourced from the harvest of previous season of each of the sites respectively.

Table 1: Resistance of the potato clones to (PLRV, PVY and PVX) according to CIP standard trials in Lima Peru

\begin{tabular}{lllllll}
\hline CIP No & $\begin{array}{l}\text { PLRV } \\
\text { Resistance }\end{array}$ & $\begin{array}{l}\text { PVY } \\
\text { Resistance }\end{array}$ & $\begin{array}{l}\text { PVX } \\
\text { Resistance }\end{array}$ & $\begin{array}{l}\text { Late blight } \\
\text { resistance }\end{array}$ & $\begin{array}{l}\text { Bacterial wilt } \\
\text { resistance }\end{array}$ & $\begin{array}{l}\text { Tuber skin } \\
\text { colour }\end{array}$ \\
\hline 395196.4 & S & ER & ER & MR & S & Cream \\
396286.6 & S & ER & ER & R & S & Purple \\
396286.7 & MR & ER & ER & R & S & Red \\
394905.8 & S & ER & ER & MR & MR & Cream \\
395438.1 & MR & ER & ER & MR & MR & Red \\
394904.17 & MR & S & ER & MR & MR & Cream \\
394903.3 & MR & ER & S & MR & MR & Cream \\
\hline
\end{tabular}

ER Extreme resistance

$S \quad$ Susceptible

MR Moderately resistant

$M R \quad$ Moderately resistant

Experimental design and crop management: The trials were planted in randomized complete block design (RCBD) with four replications. Each plot measured $3 \mathrm{~m} \times 3 \mathrm{~m}\left(9 \mathrm{~m}^{2}\right)$ with four ridges per plot spaced at $0.75 \mathrm{~m}$ apart and were planted with 40 tubers with a spacing of $0.3 \mathrm{~m}$ between the 10 consecutive tubers within a row. All crop husbandry activities followed previously described recommendations (Lung'aho et al., 2007). The crop was not sprayed with the insecticides to encourage infestation of the crop with the virus vectors (aphids) and subsequent natural virus transmission during the cropping period. The crop was harvested at full physiological maturity.

Data collection and analysis: Data were collected on number of tubers per plant and the marketable tuber weight at harvest of every season. Tuber yields $(\mathrm{T} / \mathrm{Ha})$ per season were used to calculate percentage yield reduction between seasons. All the data 
collected were subjected to analysis of variance (ANOVA) using General statistics (GENSTAT) software (Lawes, 1995). The differences between the means were compared using least significant difference at LSD 0.05 (Steel and Torrie, 1980).

\section{RESULTS}

Yield reduction over seasons: All the seven CIP sourced genotypes with multiple virus resistance experienced significant $(P \leq 0.05)$ lower yield losses over the four cropping seasons compared to the local Kenyan and Ugandan varieties (Table 2). Percentage yield reduction ranged from $58.1 \%$ to $58.5 \%$ among the susceptible Ugandan varieties and $55.6 \%$ to 56.5 $\%$ in Kenyan varieties while the CIP sourced virus resistant clones ranged between $4.6 \%$ to $32.8 \%$. The CIP clones were found with only $21.2 \%$ yield reduction compared to $68.4 \%$ in local varieties (Kenyan and Ugandan) which was a $43.6 \%$ difference in the overall mean percentage yield reduction. The lowest percentages of yield reduction were found in CIP 396286.6, CIP 396286.7 CIP 394905.8 and CIP 395438.1 with $4.6 \%, 6.9 \%, 7.3 \%$ and $11.5 \%$ respectively. Percentage yield reduction in the four clones were significantly $(P \leq 0.05)$ lower than those of the rest of the other CIP clones, CIP 395196.4, CIP 394904.17 and CIP 394903.3 which had $24.5 \%, 29.4 \%$ and $32.8 \%$ respectively. The most virus resistant local variety (Tigoni with $55.6 \%$ ) had significantly $(P \leq 0.05)$ higher percentage of yield reduction than the most susceptible (394903.3 with $32.8 \%$ ) CIP clones evaluated.

Table 2: Mean percentage yield reduction during the 2007 and 2008 cropping seasons in the trial conducted at Tigoni and at Molo

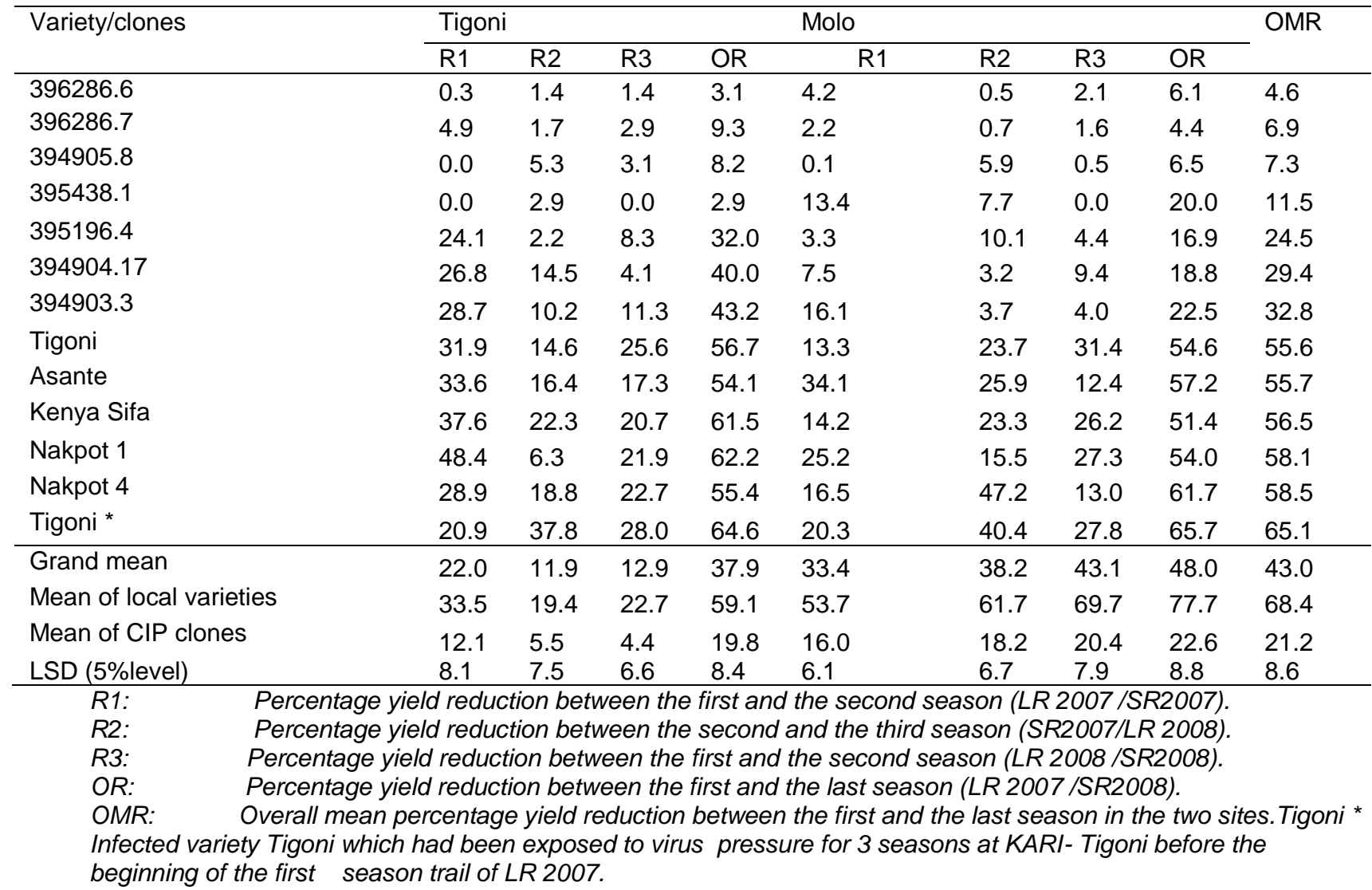


The overall percentage in yield reduction over the four cropping seasons was highest in variety Tigoni* $(65.1 \%)$ which had been exposed to virus infection prior to the start of the first season. The high initial virus incidence (at the beginning of the first season) in the seed of variety Tigoni* contributed to significantly $(P \leq 0.05)$ higher percentage yield loss compared to that of variety Tigoni.
Tuber yield (T/ha): A higher yielding virus resistant clone was identified during the exposure to natural virus pressure over the four cropping seasons in the two sites (Table 3). This clone, CIP 396286.7 which produced an average of (30.3 T/ha) was found with significant $(P \leq 0.05)$ higher yield than the highest yielding local variety, Tigoni which produced 24.3 T/ha.

Table 3: Tuber yield (T/ha) during the cropping seasons of 2007-2008 in the trial conducted at Tigoni and Molo

\begin{tabular}{|c|c|c|c|c|c|c|c|c|c|c|c|}
\hline \multirow{2}{*}{$\begin{array}{l}\text { Variety/ } \\
\text { clone }\end{array}$} & \multicolumn{5}{|l|}{ Tigoni } & \multicolumn{6}{|l|}{ Molo } \\
\hline & $S^{1}$ & $S^{2}$ & $\mathrm{~S}^{3}$ & $S^{4}$ & $M^{1}$ & $S^{1}$ & $S^{2}$ & $S^{3}$ & $S^{4}$ & $\mathrm{M}^{2}$ & $\mathrm{M}^{12}$ \\
\hline 396286.7 & 36.4 & 34.6 & 34.0 & 33.0 & 34.5 & 26.2 & 25.6 & 25.4 & 25.0 & 25.5 & 30.3 \\
\hline 396286.6 & 29.4 & 29.3 & 28.9 & 28.5 & 29.0 & 24.5 & 23.5 & 23.0 & 23.0 & 23.5 & 26.5 \\
\hline 395196.4 & 29.4 & 22.3 & 21.8 & 20.0 & 23.4 & 33.8 & 32.7 & 29.4 & 28.1 & 31.0 & 25.4 \\
\hline Tigoni & 38.3 & 26.1 & 22.3 & 16.6 & 25.8 & 39.9 & 34.6 & 26.4 & 18.1 & 29.7 & 24.3 \\
\hline Asante & 45.8 & 30.4 & 25.4 & 21.0 & 30.7 & 39.7 & 26.2 & 19.4 & 17.0 & 25.6 & 24.3 \\
\hline 394903.3 & 34.5 & 24.6 & 22.1 & 19.6 & 25.2 & 31.0 & 26.0 & 25.0 & 24.0 & 26.5 & 23.8 \\
\hline 394904.17 & 31.0 & 22.7 & 19.4 & 18.6 & 22.9 & 26.1 & 24.2 & 23.4 & 21.2 & 23.7 & 21.8 \\
\hline Nakpot 1 & 39.7 & 20.5 & 19.2 & 15.0 & 23.6 & 34.8 & 26.0 & 22.0 & 16.0 & 24.7 & 20.3 \\
\hline Nakpot 4 & 33.6 & 23.9 & 19.4 & 15.0 & 23.0 & 35.0 & 29.2 & 15.4 & 13.4 & 23.2 & 19.9 \\
\hline 394905.8 & 20.7 & 20.7 & 19.6 & 19.0 & 20.0 & 20.4 & 20.4 & 19.2 & 19.1 & 19.8 & 19.7 \\
\hline Kenya Sifa & 33.8 & 21.1 & 16.4 & 13.0 & 21.1 & 24.9 & 21.4 & 16.4 & 12.1 & 18.7 & 17.4 \\
\hline 395438.1 & 20.6 & 20.6 & 20.0 & 20.0 & 20.3 & 12.5 & 10.8 & 10.0 & 10.0 & 10.8 & 16.0 \\
\hline Tigoni * & 25.4 & 20.1 & 12.5 & 9.0 & 16.8 & 30.3 & 24.2 & 14.4 & 10.4 & 19.8 & 15.3 \\
\hline Grand mean & 32.2 & 24.4 & 21.6 & 19.1 & 24.3 & 29.2 & 25.0 & 20.7 & 18.3 & 23.3 & 21.9 \\
\hline Mean of local varieties & 29.6 & 22.6 & 20.4 & 18.0 & 22.6 & 27.1 & 24.3 & 21.1 & 18.6 & 22.8 & 21.1 \\
\hline Mean of CIP clones & 34.5 & 25.9 & 22.7 & 20.0 & 25.8 & 30.9 & 25.5 & 20.4 & 18.0 & 23.7 & 22.6 \\
\hline LSD (5\%level) & 6.2 & 4.1 & 5.5 & 5.8 & 4.9 & 6.4 & 7.7 & 7.0 & 5.4 & 5.5 & 5.9 \\
\hline
\end{tabular}

$\mathrm{S}^{1}$ The mean tuber yield in the first season trial.

$S^{2}$ The mean tuber yield in the second season trial.

$S^{3}$ The mean tuber yield in the third season trial.

$S^{4}$ The mean tuber yield in the fourth season trial.

$M^{1}$ Mean tuber yield of the trial conducted at Tigoni.

$M^{2}$ Mean tuber yield of the trial conducted at Molo.

$M^{12}$ Overall mean of both sites (Tigoni and Molo).

All the CIP sourced virus resistant clones used in this study except 394903.3 and 394904.17, did not experience any significant $(P \leq 0.05)$ yield loss over the four cropping seasons. The local Kenyan and Ugandan varieties yielded significantly $(P \leq 0.05)$ higher than the CIP sourced virus resistant clones during the first season (LR 2007) but after severe exposure to virus infection by the end of the fourth season (LR 2008), the local varieties yielded less than the CIP clones. During the second (SR 2007) and the third (LR 2008) seasons, there was no significant $(P \leq 0.05)$ difference in mean yield between the CIP and the local varieties. There was more rapid decline in yield in the local Kenyan and 
Ugandan varieties than in the CIP sourced virus resistant clones over the four cropping seasons.

Seed source with higher virus incidence experienced lower yields that those which were less infected at the beginning of the trial. Virus infected variety Tigoni (denoted Tigoni ${ }^{*}$ ) which had been exposed to virus pressure for 3 seasons at the beginning of the first season experienced significantly lower yield $(P \leq$ $0.05)$ compared to similar variety Tigoni which had not been exposed. There was no signifiant $(P \leq 0.05)$ difference in mean yield of the two sites.

Number of tubers per plant: Over the four cropping seasons, the CIP sourced virus resistant clones produced higher number of tubers per plant than the local cultivars (Table 4). Mean number of tubers per plant in the CIP clones was 12.1 and was significantly $(P \leq 0.05)$ higher than that of the cultivars which was7.3. The tuber numbers per plant in the CIP clones ranged from 8.8 to 17.8 while that of the cultivars was from 4.0 to 8.2 . The highest number of tubers was found in CIP 394903.3 which produced significant $(P \leq 0.05)$ higher number of tubers than the rest of the genotypes evaluated. Four CIP clones, (CIP 394903.3, CIP 394905.8, CIP 395196.4 and CIP 396286.7) produced significant ( $P \leq 0.05$ ) higher number of tubers per plant $(17.8,13.0,12.0$ and 11.8 respectively) than variety Tigoni, the local variety with the highest number of tubers.

Table 4: Number of tubers per plant during the cropping seasons of 2007-2008 in the trial conducted at Tigoni and Molo

\begin{tabular}{|c|c|c|c|c|c|c|c|c|c|c|c|}
\hline \multirow{2}{*}{$\begin{array}{l}\text { Variety/ } \\
\text { clone }\end{array}$} & \multicolumn{5}{|c|}{ Tigoni } & \multicolumn{6}{|l|}{ Molo } \\
\hline & $\mathbf{S}^{1}$ & $\mathrm{~S}^{2}$ & $\mathrm{~S}^{3}$ & $\mathrm{~S}^{4}$ & $M^{1}$ & $S^{\prime}$ & $\mathrm{S}^{2}$ & $\mathrm{~S}^{3}$ & $\mathrm{~S}^{4}$ & $\mathbf{M}^{2}$ & $M^{12}$ \\
\hline 394903.3 & 19.1 & 17.3 & 17 & 16.6 & 17.5 & 18.6 & 18.4 & 17.8 & 17.5 & 18.1 & 17.8 \\
\hline 394905.8 & 14.1 & 13.8 & 13.1 & 12.8 & 13.5 & 13.4 & 12.8 & 12 & 12 & 12.6 & 13.0 \\
\hline 395196.4 & 12.2 & 12 & 11.5 & 11.2 & 11.7 & 12.8 & 12.4 & 12.1 & 12 & 12.3 & 12.0 \\
\hline 396286.7 & 12.8 & 12.5 & 12.4 & 12.2 & 12.5 & 11.5 & 11.3 & 10.9 & 10.6 & 11.1 & 11.8 \\
\hline 396286.6 & 11.1 & 11 & 10.9 & 10.6 & 10.9 & 12.2 & 11.8 & 11.5 & 11.5 & 11.8 & 11.3 \\
\hline 395438.1 & 9.6 & 9.4 & 9.3 & 9.1 & 9.4 & 10.5 & 10.2 & 10.1 & 9.5 & 10.1 & 9.7 \\
\hline 394904.17 & 9.1 & 9.1 & 8.9 & 8.7 & 9.0 & 9.7 & 8.6 & 8.4 & 8.2 & 8.7 & 8.8 \\
\hline Tigoni & 12.2 & 8.5 & 5.5 & 4.2 & 7.6 & 13.4 & 9.4 & 6.5 & 5.6 & 8.7 & 8.2 \\
\hline Asante & 11.7 & 8.4 & 6.4 & 3.2 & 7.4 & 13.4 & 9.5 & 7.4 & 4.5 & 8.7 & 8.1 \\
\hline Nakpot 4 & 12.6 & 7.7 & 6.5 & 4.9 & 7.9 & 11.2 & 7.2 & 6.1 & 5 & 7.4 & 7.7 \\
\hline Kenya Sifa & 12.6 & 9.6 & 5.4 & 4.8 & 8.1 & 10.4 & 7.8 & 5.5 & 3 & 6.7 & 7.4 \\
\hline Nakpot 1 & 8.7 & 6.2 & 4.1 & 2.5 & 5.4 & 7.6 & 5.9 & 4.8 & 3.2 & 5.4 & 5.4 \\
\hline Tigoni * & 7.6 & 4.8 & 3.4 & 2.1 & 4.5 & 5.9 & 4.2 & 2.5 & 1.7 & 3.6 & 4.0 \\
\hline Grand mean & 11.8 & 10.0 & 8.8 & 7.9 & 9.6 & 11.6 & 10.0 & 8.9 & 8.0 & 9.6 & 9.6 \\
\hline Mean of local varieties & 11.6 & 8.1 & 5.6 & 3.9 & 7.3 & 11.2 & 8.0 & 6.1 & 4.3 & 7.4 & 7.3 \\
\hline Mean of CIP clones & 12.6 & 12.2 & 11.9 & 11.6 & 12.1 & 12.7 & 12.2 & 11.8 & 11.6 & 12.1 & 12.1 \\
\hline LSD (5\%level) & 2.1 & 3.4 & 2.6 & 3.2 & 3.3 & 3.4 & 2.8 & 3.1 & 1.7 & 2.9 & 3.1 \\
\hline
\end{tabular}

$S^{\prime}$ The mean number of tubers per plant in first season trial

$S^{2}$ The mean number of tubers per plant in second season trial

$S^{3}$ The mean number of tubers per plant in third season trial

$S^{4}$ The mean number of tubers per plant in fourth season trial

$M^{1}$ Mean number of tubers per plant of the trial conducted at Tigoni

$M^{2}$ Mean number of tubers per plant of the trial conducted at Molo

$\mathrm{M}^{12}$ Overall mean of both sites (Tigoni and Molo) 


\section{DISCUSSION AND CONCLUSION}

Yield reduction over seasons: The minimized rate of yield loss among the CIP sourced clones used in this study was attributed gene action of multiple resistances in the genotypes. Like in this study, degeneration of potato yield over generations of using the same seed stock depends mainly on variety grown among other factors (Rahman et al., 2010). This is due to difference in mechanisms favouring virus particle multiplication within the plant (Salazar, 1996). More accelerated yield losses occur when there is multiple infection of the crop by different viruses which increases severity of the diseases (Beukema and van der Zaag, 1990; Hide and Lapwood, 1992). Multiple virus infection is common in Kenya where most important viruses include PLRV, PVY and PVX usually occur in combination with other mild viruses such as PVA, PVM and PVS to cause even more severe crop losses (Kabira et al., 2006; Schulte-Geldermann et al., 2012). Varieties such as Asante, Tigoni and Kenya Sifa used in this study have been reported to experience significant yield losses when exposed to viruses in the field (Lung'aho et al., 2005; Muthomi et al., 2009). Frequent insecticide sprays to control aphids (virus vectors) are also known to raise environmental concerns (Salazar, 1996). In Kenya, smallholder farmers can not afford the pesticides and certified seed tubers are the majority (Kanguongo et al., 2008; Muthoni and Nyamongo, 2009). To grow virus susceptible local varieties, farmers are usually advised to replace their seed with a certified seed more frequently (Muthoni and Nyamongo, 2009; Rahman et al., 2010). With the use of genotypes with multiple resistances to viruses, such farmers would be able to grow their crop over more seasons with less rapid yield reduction while maintaining better seed quality.

Tuber yield (T/ha): Genotypes with multiple virus resistance exhibited higher yield potential when exposed to natural sources of virus infection in the field than the popularly cultivated local varieties. Higher yielding CIP 396286.7 identified in this study would automatically pass the standard yield requirement for release recommendation at national performance trials (NPT) normally conducted by the Kenya Plant Health Inspectorate Service (KEPHIS) due to it's higher yields compared to that of highest yielding local variety, Tigoni (Lung'aho et al., 2006). Such higher yielding varieties with additional desirable agronomic and market demanded attributes fit for the whole potato value chain are highly demanded by local farmers and consumers
(Kaguongo et al., 2008; Ooko and Kabira, 2011). Natural exposure to virus infection in this study simulated real cropping situation (Davies et al. 1975) common among many small holder farmers in Kenya, many of whom do not know how to manage seed borne viruses (Gildermacher et al., 2011). Field exposure has been used in the past to determine to determine level of virus resistance under natural conditions and to be sure that the results obtained are relevant to the real crop situation (Davies et al., 1975; Solomon and Barker, 2001). Number of seasons of exposure to natural virus infection in the field are important in determining virus incidence and the potential yield loss (Gildermacher et al., 2011). Selection for higher yields, multiple virus resistance in addition to other traits such as resistance to late blight (Phytophthora infestans), good storability, early maturity, good storability and good cooking and processing qualities will increase acceptability of new varieties across the whole Kenyan potato value chain (Kaguongo et al., 2008; Ooko and Kabira, 2011). From this experiment, it was evident that, such genotypes can be succesfully introduced and utilized under the Kenyan potato growing conditions. More virus resistant clones should be evaluated and released to increase availability of virus resistant varieties suiting diverse consumer niches while improving crop yields and seed tuber quality.

Number of tubers per plant: Multiple virus resistance in CIP sourced clones lowered the rate of reduction of number of tubers over seasons. Reduction in number of tubers in virus as observed in susceptible local varieties in this study corresponded to reduced in yield and tuber quality. This has been also been reported by other authors in experiments where potato crop was subjected to natural virus pressure and there by reducing the crop yields (Hide and Lapwood, 1992; Omer and El-Hassan, 1992; Rahman et al., 2010). Tuber sizes and quality can determine marketability of tubers for consumption and for processing (Ooko and Kabira, 2011). With virus resistant potato varieties, local farmers will grow their crop more profitably with reduced virus related crop losses.

\section{ACKNOWLEDGEMENTS}

Much thanks to collaboration between KARI-Tigoni, CIP-Sub-Saharan Africa Office Nairobi and the University of Nairobi for conceptualizing and facilitating this research work. 


\section{REFRENCES}

Beukema, H. P and van der Zaag, D. E (1990). Introduction to potato production.PUDOC.Wageningen, Netherlands. p 207.

CIP (2006). Standard evaluation trials database, International Potato Centre(CIP) at http://research.cip.cgiar.org/confluence/display/CPV/C atalog. (Accessed in April 2006).

Davies, H.T., McEwen, H. L., Dixon, N. C(1975). Field testing potatoes for resistance to leaf roll and virus Y.Am. Pot. Journal. 52(5):151-155.

Gildemacher, P. R., Schulte-Geldermann, E.,Borus, D., Demo, P., Kinyae, P., Mundia, P., Struik, P.C (2011). Seed potato quality improvement through positive selection by smallholder farmers in Kenya.Potato Research. Volume 54, Issue 3, pp 253266.

Gildemacher, P. R (2012). Innovation in seed potato systems in Eastern Africa.PhD ThesisWageningen University, Netherlands. pp12-13.

Hide, G. A and Lapwood, D.H (1992). Disease aspects of potato production. In: The potato crop. The scientific basis of potato improvement. Second Edition (By Paul Harris), USA.pp 403-437.

Jayashige,U., Chuquillanqui, C and Salaza,r L. F (1989). Modified expression of virus resistance in mixed virus infection in potato. Am. Pot. J. 66(3): 137-144.

Kabira, J. N., Wakahihu, M., Wagoire, W., Gildemacher, P and Lemaga, B (2006). Guidelines for production of healthy seed potatoes in East and Central Africa.Edited by LusikeWasilwa, Kenya Agricultural Research Institute, Nairobi,Kenya.pp 1-28.

Kaguongo, W.P., Gildemacher, P., Demo, P., Wagoire, W., Kinyae, P., Andrade, J., Forbes, G., Fuglie,K and Thiele, $G$ (2008). Farmer practices and adoption of improved potato varieties in Kenya and Uganda.International Potato center (CIP), Lima, Peru. Social Sciences Working Paper 2008-5.85 p.

Lawes (1995). Lawes Agricultural Trust, Rothamsten Experimental Station, UK 1995.

Lung'aho, C., Nderitu, S. K., Kabira, J. N., EL-Bedewy, R., Olanya, O.M and Walingo,A (2006). Yield performance and release of four late blight tolerant varieties in Kenya. Journal of Agronomy 5(1): 57-61. pp 57-61.

Lung'aho, C., Lemaga, B., Nyongesa, M., Gildermacher, P., Kinyae, P., Demo, P and Kabira, J (2007). Commercial seed potato production in eastern and central Africa.Kenya Agricultural research Institute, Nairobi, Kenya. pp 1-140.

Machangi, J. M., Olubayo, F. M., Njeru, R. W., Nderitu, J. H., El-Bedewy, R.,Yobera, D. M and Aura, J. A(2004). Occurance of four major potato viruses in three main potato growing areas in Kenya. 6th Trienieal conference, April 2004. African Potato association (APA). pp 273 - 281.

MoA (2005). Potato Industry Strategic Plan 2005-2014. Ministry of Agriculture (MoA) strategy for developing potato industry in Kenya, August 2005.pp 1-34.

MOA/GTZ-PSDA (2009). National Potato Taskforce Report 2009.Final Report.Ministry of Agriculture (MoA) and Germany Technical Cooperation (GTZ)-private Sector Developpement Agency (PSDA), Nairobi-Kenya. pp 110.

Muthomi, J. W., Nyaga,J. N., Olubayo,F. M., Nderitu,J. H, Kabira,J. N., Kiretai, S. M., Aura,J. A and Wakahiu,M (2009). Incidence of aphid transmitted viruses in farmer based seed potato production in Kenya. Asian J. of PI. Sci. 8(2):166-171.

Muthoni, J and Nyamongo, D. O (2009). A review of constraints to ware Irish potatoes production in Kenya.J. of Hort. and Forestry Vol. 1(7). pp. 098-102.

Nderitu, J. H and Mueke, J. M (1986). Aphid infestation on eight potato cultivars (SolanumtuberosumL.).in Kenya. Insect Sci. Applic. 7(5): 667 -682.

Olubayo, F., Kibaru, A., Nderitu, J., Njeru,R and Kasina, M (2010). Management of aphids and their vectored diseases on seed potatoes in Kenya using synthetic insecticides, mineral oil and plant extract.J. Innov. Dev. Strategy 4(2):1-5.

Omer,A and El-Hassan, S (1992). Incidence of potato viruses and their effect on potato production in the Sudan. Crop Protection.Volume 11, Issue 5. pp 477486.

Ooko, G. A and Kabira, J. N (2011). Suitability of three newly released Kenyan potato varieties for processing into crisps and French fries. African J. of Agric. Food, Nut.and Dev.Vol 11 No. 6.pp 5266 - 5281.

Rahman, M. S., Akanda, A. M., Mianm, I. H.,Bhuia and, K. A and Karim M. R (2010). Growth and yield performance of different generations of seed potato as affected by PVY and PLRV.Bangladesh J. Agric. Res. 35(1): 37-50.

Salazar, L. F (1996). Potato viruses and their control. International Potato Centre, Lima Peru. pp 6-7.

Schulte- Geldermann, E., Gildemacher, P. R and Struik, P. C (2012). Improving seed health and seed performance by positive selection in three Kenyan potato varieties. Am. J. Pot. Res. (Accepted 13-042012).

Solomon-Blackburn, R. M and Barker, $H(2001)$.A review of host major-gene resistance to potato viruses $\mathrm{X}, \mathrm{Y}, \mathrm{A}$ and $V$ in potato, genes, genetics and mapped locations. Heredity,86: 8-16.

Steel, R.G.D and Torrie, J. H (1980).Principles and procedures of statistics.A biometrical approach. McGraw and Hill Inc. pp86-191. 